\title{
データベースの初歩と, 現在の活用例
}

\section{甲木 洋介*}

\section{1. はじめに}

現代の日常生活において, IT(Information Techno$\log$ : 情報技術) はもはや当たり前のものになりつつ ある。ポータルサイトから日々配信されるニュース， ソーシャル・ネットワーキング・サービス $(\mathrm{SNS}) に よ$ るコミュニケーション, 電車の乗り換えの検索に至 る。これらのサービスでは, 膨大な量のデータで構成 され，そのデータは目的に応じて高速に検索される。 これらの事が可能になっているのは，それぞれのサー ビスに拈いてデータが“データベース”として整理され ているためである.

しかし，一般のサービス利用者にとって，データ ベースというものは馴染みが無い分理解し辛く, そも そも何故データ管理にデータベースが必要なのか, 表 計算ソフトとはどう管理が異なるのか, という疑問が 少なからず沸いてくる。 また，いざデータべースを構 築，管理するという立場に立たされた時には，意外に データベースについて知らないことが多く，実際の想 定とはかけ離れた運用をしてしまい, 性能などで様々 な問題を発生させてしまうことも多い.

本稿では, データベースに興味がある, もしくは研 究目的でデータベースをこれから理解しなければなら ない人に向けて，データベースとは何か，実践的な活 用例について紹介すると共に, キー・バリュー・スト ア (KVS)の活用に至る今後のデータベースのあり方に ついても考える.

\section{2. データベース}

2.1 データベースとは

データベースとは, “一定の規則に従って整理され た，データの集合体”を指す。そのため，データの整 理方法が定義されていない単なるデータの塊, 例えば カンマ区切りのテキストファイルはデータベースとは 言えない.

\footnotetext{
$\dagger$ The first step and the present example of practical use of a database

Yosuke KATSUKI

* 日本オラクル株式会社 オラクルユニバーシティ Oracle University, Oracle Corporation Japan
}

データベースの構造を“データモデル”と呼んでい る。データモデルには,

・階層型

・ネットワーク型

・リレーショナル型

・オブジェクト型

等の種類がある.Webアプリケーションを目にする機 会が増えている。 その基幹に打いてリレーショナル型 のデータモデルが多く利用されている。リレーショナ ル型のデータベースは, 英語 (Relational Data Base) の頭文字を取って“RDB”，それを管理するソフト ウェアを“RDBMS”という。

\subsection{RDB}

\subsection{1 リレーショナルモデルの構造}

RDBの歷史は，1970年にEdgar Frank Coddが論文 で発表した [1][2].リレーショナルモデルは, 集合 論と述語論理に基づいて考案されたモデルで, 同じ性 質を持つ情報の集合を“テーブル”と呼び，レコード (行)及びカラム(列)で構成する。一つのテーブルは, 同じ性質 (情報の属性)を持ったデータで構成する。異 なる性質のデータは別のテーブルとする。それぞれの テーブルは, リレーション(関係) という情報で関連性 を持たせることで, 扱いたいデータの構造を表現して いる(図 1 )。

例えば会社を構成している部署と，各部署に所属し ている社員をリレーショナルモデルで表現すると図 1 のようになる。

一つのレコードは一人の社員や一つの部署を表し， カラムには同じデータ型を持つ同じ種類の情報 (社員

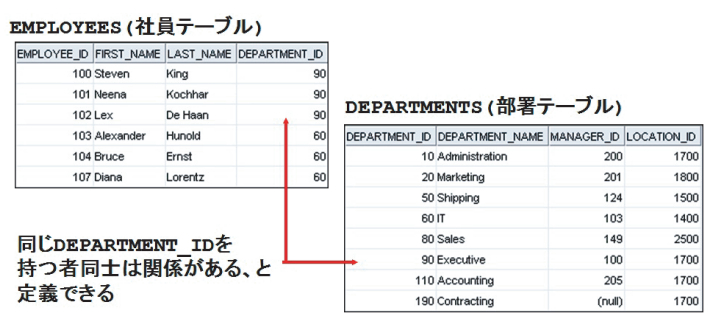

図 1 リレーショナルモデルのイメージ 
番号や社員名など)が並ぶ。社員テーブルは, 社員番 号 (EMPLOYEE_ID) や苗字(LAST_NAME)等の属性 を持ち, 部署テーブルにそれらの情報が無い。代わり に部署テーブルには, 部署の情報を表現するのに必要 な属性として，部署名(DEPARTMENT_ID)や部署の 責任者の社員番号 (MANAGER_ID)等が与えられてい る。そしてRDBでは集合論でデータを管理する為, 表計算ソフトの場合と違って，データを格納する際に 行番号という概念が存在しない，そこでこられのテー ブルには，一般的に行を識別する為の“主キー”と呼ば れるカラムを設けている（図1では, 社員テーブルの EMPLOYEE_IDと, 部署テーブルのDEPARTMENT_ID が該当する)。このようにして，情報をテーブル構造 とリレーションで定義したものがRDBである.

\subsection{2 データベースの正規化}

正規化とは, データの一貫性の保持とデータ管理領 域の効率化を目的に行う作業である。

\section{[第一正規形]}

同じデータが繰り返し現れているカラムを別テーブ ルに分割し主キーを与え，重複を排除する。また，計 算で導出できる項目を削除し, データ保存領域の効率 化を図る。

\section{[第二正規形]}

部分関数従属, つまり主キーに依存せず，別のカラ ムに依存するカラムを排除する。例えば，注文を管理 するテーブルを構成する時に, 注文データ一件一件の 中に商品の具体的な品名や単価は入れない。これら商 品の詳細情報は商品テーブルとして別に分割し, リ レーションでキーだけを残す形にするのが望ましい.

\section{[第三正規形]}

第二正規形をもう一歩進めて，主キーに間接的に従 属している項目を排除する.

正規化はこれら第一一第三以外にも第四，第五正規 形や，ボイス・コッド正規形 [3]等が知られている.

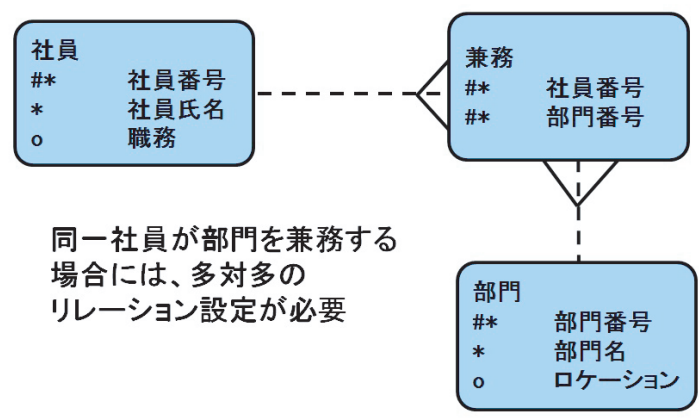

図 2 多対多のリレーション設定例
一般的なWebアプリケーションの開発における正規化 は，第三正規形まで適用できていればとりあえず十分 だが，実際には一対多のリレーション以外にも多対多の リレーションが発生する事があり，その対応として中 間テーブルを配置する等の工夫が必要になる(図 2 ).

大規模なデータをRDBMSで効率良く利用する為に は，テーブルを正規化しておくことが望ましい。

\section{3 構造化問い合わせ言語SQL}

$\mathrm{RDB}$ の操作，例えばテーブルの作成やデータの検 索や挿入を行う場合には，RDBを操作する為に開発 された専用の言語，SQL(Structured Query Language: 構造化問い合わせ言語)を使用する。

SQLはANSI (米国国家規格協会) PISO (国際標準化 機構)で認定された言語である[5]。RDBMSはこの SQLを解釈し，RDBに対して適切な操作を行う。

\section{3．大規模データを用いた実装例}

本稿では, データベース操作の実例を気象庁の「ア メダス観測年報 (時日別值テキストファイル版) $\mathrm{CD}$ $\mathrm{ROM} 」$ の 1993年から 1998年までの積雪を含まない 6 年 分のデータを用いて示す。

\section{1 気象観測年報データ}

気象庁は，アメダス (AMeDAS)による観測を, 昭 和49年11月 1 日から開始した。全国の約1300地点で 行われている。観測項目には, 降水量, 風向・風速, 気温，日照時間等があり，固定長テキストデータの場 合，各年 $18 \mathrm{MB}$ 程度のサイズがある。実装環境は， Core2 Duo 2.5GHz，8GBメモりを搭載したWindows7 $\mathrm{PC}$ 上のOracle Database 11g Enterprise Editionである.

\section{2 データの正規化}

アメダスのデータは, 観測地点毎に降水量や気温等 の異なる種類の気像データを順次ISDN回線等を使っ て転送する仕組みになっている [6]，そのため，デー 夕構造もテーブル形式ではあるが, 決められた数の列 に異なる種類のデータが格納されている(表 1 ).

まず種類の異なるデータをそれぞれのテーブルに分 る。これにより各テーブルは観測值番号と年月日で相

\section{表 1 アメダスデータ構造}

\begin{tabular}{|c|c|c|c|c|}
\hline 1列目 & 観測所番号 & 観測所番号 & 観測所番号 & 観測所番号 \\
\hline 2列目 & 钼測所データ位置番号 & 钼測所デー夕位置番号 & 钼測所データ位置番号 & 钼測所デー夕位置番号 \\
\hline 3列目 & 年 & 年 & 年 & \\
\hline 4列目 & 月日 & 月日 & 月日 & 月日 \\
\hline 5 列目 & 㱠 & 2 & 3 & 4 \\
\hline 6列目 & 1時までの降水量 & 1時の風向と風速 & 1時までの日照時間 & 1時の気温 \\
\hline 27 列目 & 24時䒠での降水量 & 24時の風向と風速 & 24. & 24晆の気温 \\
\hline 28列目 & 1日降水量 & 1日平均風速 & 1日日照時間 & 1日平均気温 \\
\hline 29列目 & データ状態 & $\vec{\tau}-$ 状態 & データ状態 & データ状態 \\
\hline 30 列目 & 日最大 1 時間降水量 & 旦最大風速 & 9999 & 日最高気温 \\
\hline 31 列目 & 9または9999 & 旦最大風速の風向 & 9999 & 日最低気温 \\
\hline
\end{tabular}




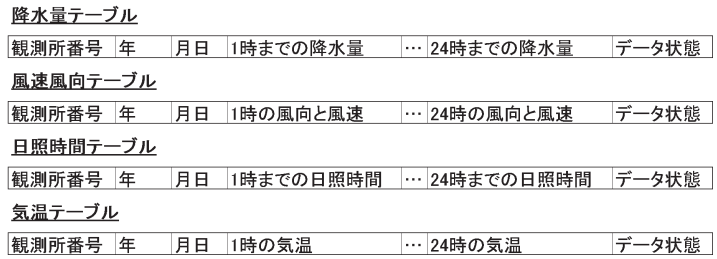

图 3 再編成したアメダスのデータ構造

\section{互に参照できる.}

次に，導出項目を削除した(表 1.28 列目，30列 目)。以前は計算コストを削減する為に, 導出項目を 予め算出した上でテーブル上に保持して置く事が多 かった．現在は正規化を崩してまでて長なデータを持 つメリットは薄れてきている。これはシステムの性能 が以前と比較して高速化したことも挙げられるが，導 出項目の操作をプログラミング言語側で行うと, 後で データ更新が発生した場合, 整合性の保証管理が複雑 になるというデメリットが発生してしまう事が大きな 理由である。

参考までに，日照時間が 12 時間以上あった観測記 録，約 2 万 6000 件を検索する際に，日毎の日照時間 の合計值を使用した場合 10.03 秒，その場で合計值を 算出した場合 11.63 秒であった。

正規化によって，保持すべきデータ量の削減と，目 的に合ったアクセス対象データの絞り込みを実現した (図 3 ).

\subsection{RDBMSが持つ機能の活用}

RDBMSには, 検索や更新を高速化する為の機能が数 多くあり，本稿ではその中から 3 つの方法を紹介する。

\subsection{1 インデックス}

RDBMSの検索において最も効率が悪いのが，一度 の問い合わせでテーブルを全て検索する全件検索 ( フ ルスキャン)である。この全件検索を抑止するのがイ ンデックスである。インデックスは一般書籍の巻末に ある索引と同じ働きを持つRDBMSの構成要素で, 条 件を指定するカラムに作成しておくと，検索や更新に おいて，必要なレコードのみにアクセスできるように なり, 結果として高速な操作が可能になる.

操作として，1993年 9 月に発生した平成 5 年台風 第13号[7]の九州における期間降水量の变化を集計する 場合に扔いて，インデックスがある場合とない場合で どのような性能変化が起きるかを下記に示す (表 2 ).

表 2 におけるB*Treeは, 通常のRDBMSで使用さ れるッリー構造のインデックスである $[8]$.

それに対してOracle Databaseでは，ビットマップ
表 2 インデックスの種類による検索性能比較

\begin{tabular}{|c||r||r|r|}
\hline \multicolumn{2}{|c||}{} & $\begin{array}{c}\text { 検索時間 } \\
(\mathrm{sec})\end{array}$ & $\begin{array}{c}\text { 読み込み } \\
\text { データ量 } \\
(\mathrm{MB})\end{array}$ \\
\hline \hline \multicolumn{2}{|c||}{ インデックス無 } & 7.7 & 1650 \\
\hline \multirow{2}{*}{$\begin{array}{l}\text { インデッ } \\
\text { クス有 }\end{array}$} & \begin{tabular}{l} 
B*Treeのみ使用 \\
\cline { 2 - 4 }
\end{tabular} & 1.09 & 17 \\
\hline
\end{tabular}

インデックスと呼ばれるビットマップ構造のインデッ クスも作成することができる [9]。これはデータの分 散度合いが低い場合, つまり同一カラム中に同じデー タが多数現れる場合において効果的である。

\subsection{2 パーティションテーブルの使用}

現在使われている大規模向け商用RDBMSでは， テーブルをパーティションと呼ばれる決められた単位 で区切ることができる[10][11][12]（図 4).

検索対象が特定パーティション内だけに存在する場 合，テーブルの全件検索を行わずに特定パーティショ ンのみ検索が行われる。

例えば今回のアメダスの場合は, 全体のデータを年 や月でパーティション分割することで条件に応じたアク セ又範囲を大幅に限定することが可能になる(表 3 ).

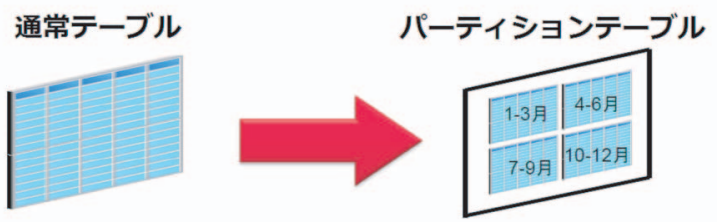

図 4 パーティションテーブルのイメージ

表 3 パーティションの有無による検索性能比較

\begin{tabular}{|c|c|c|}
\hline & $\begin{array}{l}\mid \begin{array}{l}\text { 検索時間 } \\
(\mathrm{sec})\end{array} \\
\end{array}$ & $\begin{array}{l}\text { 読み込みデータ量 } \\
\text { (MB) }\end{array}$ \\
\hline パーテイショ & 7.70 & 1,650 \\
\hline
\end{tabular}

\subsection{3 バッファサイズの拡大}

バッファとは, RDBMS上で使用される, テーブル のデータを一時的に記憶するメモリ領域のことであ る.RDBMSで頻繁に行われるデータの読み書きは, ハードディスクへ直接アクセスするよりもメモリ上で 行うと高い性能となる。しかし, データベースを構成 する際, バッファの初期值は小さいことが多い。そこ で，RDBMSがOS上で使用するバッファのサイズを増 やし，できるだけテーブルのデータがメモリに載り続 
けるよう調整するという考え方がRDBMSのチューニ ング手法として良く知られている。具体的な設定方法 はRDBMSによって異なる [13][14][15]．基本的な固 有パラメータを操作することによって, マシン搭載メ モリのアプリケーション利用可能上限值までRDBMS が使用できるように設定を行う。

\section{4 ハードウェアによる高速化}

メモリが小さい，あるいはテーブルのデータが大き 過ぎてHDDアクセスが避けられない場合は，思い 切ってデータベースが格納されるハードディスクを SSD (Solid-State Drive) に変更するという方法もある [16]。高価ではあるが (2012年 4 月現在，ハードディ スクと比較した容量当たりの単価は約 20 倍), $500 \mathrm{MB} / \mathrm{sec}$ とハードディスクの約 3 倍の高速な読み 取りと書き込み性能が得られる。

\section{4 . 現在における RDB の活用例}

冒頭でも述べた通り，現在の情報システムにおい て，RDBは欠かせないものになっている。大規模小 売店の例を挙げる。

膨大な品目を持ち, 可能な限りリアルタイムに在庫 や売上の情報を入手する必要があるコンビニエンスス トアや大型小売店にとっては, データが一元化でき, 高速に検索ができ, 経営判断に必要な情報が即座に入 手できるRDBは今やどの企業にとっても必要不可欠 なものである.

インターネット上にオンラインストアを設けている 企業では，24時間365日いつでも注文を受け付けられ るシステム要件が定義されていることもある。ざのよ うな障害が発生してもデータベースがアクセス不能に 陥らない為には，データベースを多重化(コピーを作 成して同時運用)して障害に備える等の備えも必要で ある。

\section{5 ．今後の RDB を取り巻く環境の変化}

このように, RDBは数多くのシステムの中で活用 されている, 欠かせない要素となっているのだが, 純 粋にRDBMSのみで機能性能を評価する方式から，よ り包括的にシステム全体を考えて導入する幾つかの方 式が登場している.

\section{1 データベース・アプライアンス・サーバの使用}

アプライアンスとは，“特定用途向け”という意味を 含んでいる。従来RDBMSは, ハードウェアPOSとは 別に提供され，導入者が独自にインストール，構成を 行う必要があった。しかし, 高度化する要件に合わせ
て最適な構成のシステムを作り上げるには，相応の技術 と経験が必要である。そこで, ITベンダーが事前構成 済みのサーバマシンを提供する形態が登場してきた。

データベース・アプライアンス・サーバは,

RDBMS専用マシンとして構成されている。高速な処 理を行うために必要な機能・性能を予め持ち合わせた 上で提供され，性能向上の試行錯誤を行う必要がな い。またハードウェアからRDBMSまでの全てを一社 が一括で提供しているので, トラブル発生時の問題切 り分けの負担も軽減できる.

\section{2 クラウドコンピューティングの利用}

ネットワーク越しにコンピュータのリソースを使用 するという利用形態は, 古くから“ユーティリティー コンピューティング”等の用語で表現されていた[17] が，この考え方を元に，必要に応じて様々なレベルの コンピュータリソースを契約ベースでネットワーク越 しに使用する形態が登場した。これがクラウドコン ピューティングである。

クラウドコンピューティングという言葉自体は抽象 的なもので，実態に応じて細分化できる，具体的には， ハードウェアやストレージ環境のみを提供して，OS以 上のソフトウェア構成は自前で行うHaaS(Hardware as a Service)/IaaS (Infrastructure as a Service), RDBMS等のサーバソフトウェアが構成された状態で 提供するPaaS(Platform as a Service)，更にその上で 動作するアプリケーションプログラムまで提供する SaaS (Software as a Service)等がある。

クラウドコンピューティングの登場により, 従来か ら企業で所有している情報システム, 特にハードウェ アの所有・運用コストの低減や，情報システムの突発 的な負荷対応に打けるリソースの一時的な確保等，リ ソース管理の柔軟性向上が期待されている。

\section{3 キー・バリュー・ストア $(K V S)$ の登場と普及}

\subsubsection{KVSとは}

日々，情報システム上で膨大なデータが発生してい る中, リレーショナル型のデータモデルが必須ではな いデータベースが現れてきた。具体例としては，大規 模なソーシャルネットワークやオンラインゲームで扱 われるデータが挙げられる。これらはログインした ユーザのIDに紐付くメッセージやキャラクターの画 像などの情報が単一検索できれば良く, 従来のRDB の様に統計の為のSQLや, 厳密なデータの一貫性管理 を必要としない。逆に, 処理を一か所で厳密に行う RDBでは大量の同時アクセスに伴う一貫性管理の機構 がボトルネックになり, 途端に性能が落ちてしまう。 


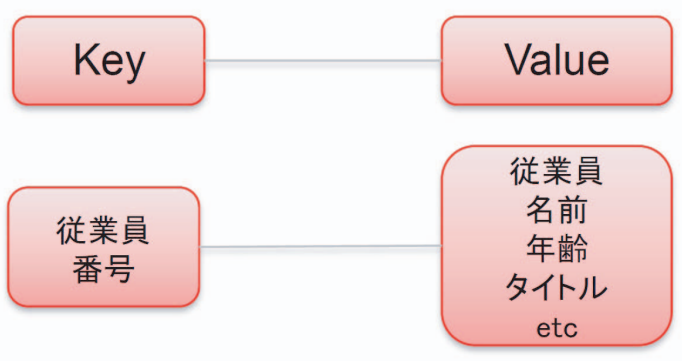

図 5 KVSに格納する従業員データの例

このような条件に適したデータ管理方法が，キー・ バリュー・ストア(以下KVS)である，KVSはプログラ ム言語における連想配列と同じように, 任意の要素を 持つデータセットにキー值を付けて，キー值を元に検 索や保存を行うという仕組みである [18](図 5 ).

\subsubsection{RDBとの相違点}

KVSもRDBも最終的には永続的にデータを保存す るという目的は変わらない。しかし, データ管理の優 先順位に対して大きな違いがあり，“CAP定理”として 知られている $[19][20]$.

CAP定理のCAPとは，それぞれ分散システムにおけ る一貫性 (Consistency), 可用性 (Availability)，ネッ トワーク分断への耐性(Tolerance to network Partitions) の 3 条件を表している。このうち現実には，2 条件ま でしか満たすことができないという考え方である。

RDBは一貫性と可用性を重視しておう，KVSは可 用性とネットワーク分断への耐性を重視している。つ まり，KVSはRDB程にデータの一貫性は保証してい ないものの, 分散処理により適した構造と言える。こ の特性を生かした製品が多数開発されており，大量の データを多数のマシンで分散処理し，全体の処理時間 を短縮する手法“MapReduce[21]”を取ることが可能 になった。

\subsection{3 大規模データへの適用と問題点・対応策}

RDBを使用した処理の場合, 前提としてデータが 正規化されている必要があるが, KVSの場合, キー值 が特定できるのであれば，データに関しての正規化は 不要である。先述のAMeDASを例に挙げると，年月 日とデータ種別区分がキーしてレコードが特定できれ ば良い。

RDBでは集計操作の殆どはSQL関数によって予め 提供されているが，KVSの場合は自作のアプリケー ションとして実装しなければならない。また，通常の KVS製品にはデータの一貫性を保つロック機構が無い 為, 必要があれば, データのロック管理も自作のアプ
リケーション側で実装する必要がある。しかしこれら の開発工数を軽減する為に, 商用製品の中には, SQL 文に近い条件式が記述できたり, ロック機構を備えた りしているものもある[22].

念の為補足するが，KVSはRDBに取って代わるも のではない，従来RDBでは不得意としている分散処 理に対してKVSが向いており, 逆に一貫性を重視する システムに打いてはRDBの方が適しているという相 互補完の関係と考える方が適切である。

\section{6. むすび}

データベースとは何か, というごく初歩的な確認か らスタートし，実践的な活用例や現在注目されている KVSの活用に至るまでの変化を追いながら, 今後の データベースのあり方について考察した。

現在ITの世界では, 新しい用語として“ビッグデー タ”という単語が良く使われている。これは，業務や 実験で得られる大量のデータの事を指している。従来 はデータ分析の為にRDBの設計等の準備が必要不可 欠とされていたが，KVSの登場によって，一旦は設計 なしのKVSに溜めておいて, 必要なデータをモデル設 計されたRDBに流しこんで分析をする，というハイ ブリッドなシステム形態が登場する兆しを見せてい る. より高速に, より大容量にというシステムの進化 はこれからも継続し，それに対応した様々な製品が登 場するであろう。

\section{参 考 文 献}

[1] E.F. Codd : A Relational Model of Data for Large Shared Data Banks, Communications of the ACM 13 (6) , pp.377-387, 1970.

[ 2 ] E.F. Codd : The Relational Model for Database Management (Version 2 ed.), Addison Wesley Publishing Company, 1990.

[ 3 ] E.F. Codd : Racent Investigations in Relational Data Base Systems, Information Processing, pp.1017-1021, 1974.

［4］穂鷹良介：リレーショナル・データベースに打ける第 3 正規形について, ソーシァル・サイエンス・ラボラ トリ（株），情報処理 $18 （ 11 ）(N o v-15-1977 ）$ ，一般 社団法人情報処理学会 pp.1139-1141, 1977.

[ 5 ] C.J. Date, Hugh Darwen : A Guide to the SQL Standard, A user's guide to the standard database language SQL, Fourth Edition, Addison-Wesley, ISBN 0-201-96426-0, 1997.

[6] 日本気象協会：アメダスについて, http://tenki.jp/ docs/note/amedas/page_1.html，2012 年 4 月 15 日.

[7] 気象庁ホームページ:災害をもたらした気象事例（台 風第 13 号）, http://www.data.jma.go.jp/obd/stats/ data/bosai/report/1993/19930901ty/19930901.html, 2012 年 4 月 15 日. 
[ 8 ] Gene Y. C. Fuh, Stefan Dessloch, Daniel Tsunfang Lee, Ping Li, Nelson Mendonca Mattos, Shahrokh Talmoud, Yun Wang : Supporting database indexes based on a generalized B-tree index, United States Patent 6219662, (9-Jul-1998)

[ 9 ] Oracle Database パフォーマンス・チューニング・ガ

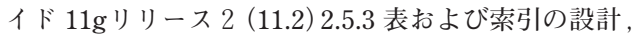
http://docs.oracle.com/cd/E16338_01/server.112/ b56312/design.htm\#CJHCJIDB，2012 年 4 月 15 日.

[10] IBM DB2 9.5 オンラインマニュアルパーティション表, http://publib.boulder.ibm.com/infocenter/db2luw/v9r5/ index.jsp?topic $=\% 2 \mathrm{Fcom} \cdot \mathrm{ibm} \cdot \mathrm{db} 2 \mathrm{luw} \cdot \mathrm{admin} \cdot$ partition.doc $\% 2 \mathrm{Fdoc} \% 2 \mathrm{Fc} 0021560 . \mathrm{html}, 2012$ 年 4 月 15 日.

[11] MSDNライブラリ : パーティションテーブルとパー ティションインデックス,

http://msdn.microsoft.com/ja-jp/library/ms188706 （v=sq1.105）.aspx，2012 年 4 月 15 日.

[12] Oracle Database 概要 $11 \mathrm{~g}$ リリース 2 （11.2） 4 パー ティション，ビュー拈よ゙その他のスキーマ・オブ ジェクト

http://docs.oracle.com/cd/E16338_01/server.112/ b56306/schemaob.htm，2012 年 4 月 15 日.

[13] IBM DB2 9.5 オンラインマニュアルバッファー・プール , http://publib.boulder.ibm.com/infocenter/db2luw/ v9r5/index.jsp?topic=\%2Fcom.ibm.db2.luw.admin.dbobj. doc\% $2 \mathrm{Fdoc} \% 2 \mathrm{Fc} 0052482 . \mathrm{html}, 2012$ 年 4 月 15 日.

[14] MSDNライブラリ:バッファ管理, http://msdn.microsoft.com/ja-jp/library/aa337525 $(\mathrm{v}=\mathrm{sql} .105) . \mathrm{aspx}, 2012$ 年 4 月 15 日.

[15] Oracle Database概要 $11 \mathrm{~g}$ リリース 2 （11.2） 7.2 バッ ファ・キャッシュの構成および使用方法,

http://docs.oracle.com/cd/E16338_01/server.112/ b56312/memory.htm\#i29118，2012 年 4 月 15 日.

[16] Kenji Tsuchiya : SSD Architecture and its Future,
IPSJ SIG Technical Report, 2010 - ARC-187（5), 28Jan- 2010.

[17] Douglas F. Parkhill : The Challenge of the Computer Utility, Addison-Wesley Publishing Company, ISBN 0240507177, 1966.

[18] Fay Chang, Jeffrey Dean, Sanjay Ghemawat, Wilson C. Hsieh, Deborah A. Wallach, Mike Burrows, Tushar Chandra, Andrew Fikes, Robert E. Gruber : Bigtable: A Distributed Storage System for Structured Data, Google, Inc. OSDI '06 pp. 205-218, 2006.

[19] Nancy Lynch and Seth Gilbert : Brewer's conjecture and the feasibility of consistent, available, partitiontolerant web services", ACM SIGACT News, Volume 33 Issue 2, pp. 51- 59, 2002.

[20] “Brewer's CAP Theorem”, http://julianbrowne.com/ article/viewer/brewers-cap-theorem, 2012 年 4 月 15 日。

[21] Jeffrey Dean and Sanjay Ghemawat : MapReduce : Simplified Data Processing on Large Clusters, Google, Inc. OSDI04 : Sixth Symposium on Operating System Design and Implementation, San Francisco, CA, December, 2004.

[22］ Oracle Coherence 開発者ガイドリリース 3.7.1 http://docs.oracle.com/cd/E26853_01/coh.371/ b65026/toc.htm, 2012 年 4 月 15 日.

(2012年 4 月16日 受付)

[問い合わせ先］

干107-0061 東京都港区北青山2-5-8オラクル青山センター 日本オラクル株式会社 オラクルユニバーシティ

甲木 洋介

TEL : $03-6834-3443$

E-mail : Yosuke.Katsuki@oracle.com

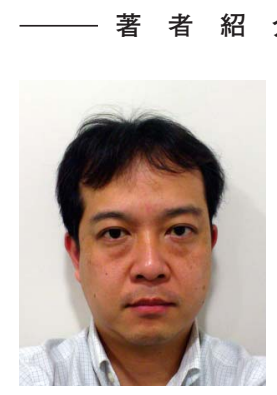

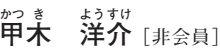

平 9 九州工業大学・情報工・制御シ ステム工学科 (現・システム創成情報 工学科) 卒. 同年 4 月日本オラクル株 式会社入社. 社内人材育成やデータ ベース製品のプリセールスを担当した 後, 平成 16 年より現職. 同社のデータ ベース製品打よびSOA (Service-Oriented Architecture) ミドルウェア製品 の技術講習に従事。著書「Oracle SQL クイズ」(翔泳社)「Oracle WebLogic Server $11 \mathrm{~g}$ 運用・構築ガイド」(同) 